Article

\title{
The Philosophical Anthropology of Erich Fromm: The Conscious and the Unconscious in Man
}

lan Raymond B. Pacquing

\begin{abstract}
The philosophical anthropology of Erich Fromm rests on his analysis of the existential dichotomy, which breaks man's humanity. When man disobeys God in paradise, he begins to become human. He begins to be free. For Fromm, disobedience is a prerequisite towards freedom. However, there is in him a yearning to go back to paradise to enjoy the "roots of his own nature." He wants to be secured and taken care by a loving God. This allegory was taken and interpreted by Fromm that man is separated from his own nature. In paradise, he is an animal. He does not possess any reason or freedom as a human being. Physiologically, he does what other creatures do. However, saying "no" to God's commandment allowed him to become human. He has reason and freedom. He is forced to take the responsibility to build his own humanity. Now, he is torn between two existential nature i.e., his animal nature and human nature. There is no way for him to return to his paradisiacal roots. He has to move on and build his true human nature. For Fromm, this can be done through reason, faith, and love.
\end{abstract}

Keywords: Fromm, existential dichotomy, neurosis, freedom

\section{Prophetic Messianism}

$\mathrm{R}$ ainer Funk, the autobiographer of Fromm, once remarked that anyone who reads the work of Fromm must begin with his concept of man. ${ }^{1}$ For Funk, this is the central issue of Fromm's thought, which must never be separated from his discussions on sociology, anthropology, religion, sciences, and technology. Any study concerning the nature of man must begin and end with man. Fromm anchors his thought on humanism, which Foreword, 9.

${ }^{1}$ Erich Fromm, On Being Human, ed. by Rainer Funk (New York: Continuum, 1999),

(C) 2014 lan Raymond B. Pacquing

http://www.kritike.org/journal/issue 15/pacquing december2014.pdf

ISSN 1908-7330

$(\mathrm{Cc}) \mathrm{BY}$-NC 
he uses to examine the world. In the words of Funk, "Fromm speaks of humanistic socialism, humanistic forms of industrial society, of a humanistic weltanschauung, of a humanistic psychoanalysis, of humanistic character structure, of humanistic ethics, of humanistic guilt ... ."2 Fromm's philosophical anthropology emanated from his early experiential influences on Judaist Hasidism under his Talmud mentor Salman Baruch Rabinkov. ${ }^{3}$ Fromm says, "My sense of the world, however, was not that of a modern man but a premodern one; and that attitude was reinforced by studying the Talmud, reading the Bible a lot, and hearing a lot of stories about my ancestors, who had all lived in a world that predated the bourgeois world." 4 The influence of Hasidism was inculcated in Fromm so that, as scholars would say, he served God with joy by singing Hasidic songs all throughout his life. 5 This early influence would be carried on by Fromm to develop what he later termed in his anthropology as "prophetic messianism." 6 This messianism is concerned with how he visualized the goal of humanity in achieving its end. ${ }^{7}$ Soon his Hasidic influences began to mix with the humanist Marxism and Freudian psychoanalysis when he entered the university in Frankfurt. This then fortified his belief on the centrality of man as the foundation of his humanistic psychology. ${ }^{8}$ In Modern Man and the Future, Fromm argued that man is in search of a unity within himself by building a social system based on reason, love, justice, and solidarity. ${ }^{9}$

Through Fromm's allegorical reading of Adam and Eve in the Genesis, he argues that there exists an existential dichotomy in man. His original state in paradise before they ate the forbidden fruit speaks of his animal nature. Man follows physiologically the dictates of his instincts just like what other creatures do. He eats, drinks, sleeps, and rests following the natural flow of his animal nature. It seems that, for Fromm, man was basically

\footnotetext{
2 Rainer Funk, "The Humanistic Foundation of Psychoanalysis According to Erich Fromm," presented at the 34 $4^{\text {th }}$ Winter-Meeting of the American Academy of Psychoanalysis (December 9, 1990), in San Antonio/Texas in commemoration of Erich Fromm's 90 th birthday, 1.

${ }^{3}$ Cf. Merkur Dan, "Erich Fromm's Humanistic Psychoanalysis," in Explorations of Psychoanalytic Mystics, 11 (2010), 71.

${ }^{4}$ Erich Fromm, For the Love of Life, trans. by Robert and Rita Kimber (New York: The Free Press, 1986), 98.

${ }^{5}$ Cf. Dan, “Erich Fromm's Humanistic Psychoanalysis," 71.

${ }^{6}$ Cf. Lawrence Wilde, "In Search of Solidarity: Ethics of Politics of Erich Fromm," in Contemporary Politics, 6:1 (2000), 4.

${ }^{7}$ This is seen in all his major works such as the Escape from Freedom (1941), Man for Himself (1947), Sane Society (1955), The Art of Loving (1957), and The Anatomy of the Human Destructiveness (1973).

${ }^{8}$ Cf. Joanne Braune, “Erich Fromm and Thomas Merton: Biophilia, Necrophilia, and Messianism" in Fromm Forum, 15 (2011), <http://www.fromm-gesellschaft.eu/images/pdfDateien/Braune_J_2011.pdf>.

${ }^{9}$ Cf. Erich Fromm, "Foreword Bellamy," in The Literary Estate of Fromm (New York, 1960).

(C) 2014 lan Raymond B. Pacquing

http://www.kritike.org/journal/issue 15/pacquing december2014.pdf

ISSN 1908-7330

(cc) $\mathrm{BY}-\mathrm{NC}$
} 
an animal in paradise. He does not possess any reason to know and to understand himself and his environment. Further, man does not even know, as he was with other creatures, that he is primarily a man. He was just one among the many creatures God created. He depends only on his instincts to survive. ${ }^{10}$

However, when Adam and Eve ate the forbidden fruit, for the first time, man became aware of himself. He now possesses reason, and his intelligence surpasses that of other creatures. It is here that history begins to unfold. He argued in Fear of Freedom that, "The most beautiful as well as the most ugly inclinations of man are not part of a fixed and biologically given human nature ... as a matter of fact, man himself is the most important creation and achievement of the continuous human effort, the record of which we call history." 11 Man had cut his ties with nature, which made him a "part of the soil of his tribe."12 For the first time, man had reached his own individuality trying to come to terms with his own self. He now begins to be conscious of himself and of his environment. His freedom and reason become a redemptive factor of his own individual autonomy. His act of disobedience is an act of becoming free. Fromm mentions that man's disobedience of God's command has an emancipatory intent for it allows man to liberate himself from the clutches of paradisiacal environment. He acknowledges that this act of disobeying God is an act of man's "owning" his individuality. ${ }^{13}$ It is an act of redeeming his own self as a human being. It is his affirmation of himself as man. Man now becomes aware not only of himself, but of recreating and perfecting his own individual self. He becomes conscious of his own desires, wishes, and fantasies. Man now enjoys his own freedom, his own individual self. As a conscious being, he now begins to transform his environment in order to become more human. ${ }^{14}$ However, by regaining his humanity, he is

${ }^{10}$ Cf. Braune's argument on the messianism of Fromm in "Erich Fromm and Thomas Merton." See also Fromm's discussion on the human situation in the Sane Society (New York: Holt, Rinehart, and Winston, 1955), 22-24; Man for Himself: An Inquiry into the Psychology of Ethics (New York: Henry Holt and Company, 1990), 4-5; Revolution of Hope (New York: American Mental Health Foundation, Inc., 1970), 59; You Shall be as Gods, 53. See also Fromm's rejection of the libido theory of Freud in his book, The Greatness and Limitation of Freud's Thought where he argued for man's liberation through productive character orientation.

${ }^{11}$ Erich Fromm, Fear of Freedom (US: Farrar \& Rinehart, 1942), 9.

${ }^{12}$ Fromm, On Being Human, 160.

${ }^{13}$ Cf. Fromm's discussion of man wanting to be like God in You Shall be as Gods, 53. Further, Funk's reiteration on the Marxist element of Fromm's work would affirm commentators like Jay, Kellner, Mclaughlin, and Wiggershaus that his psycho-social philosophy became the ground for the members of the Frankfurt School in analyzing the pathology of society. For further discussion see Rainer Funk, Erich Fromm: The Courage to be Human (New York: Continuum, 1982), 67.

${ }^{14}$ Cf. Fromm, "Foreword Bellamy," 2.

(c) 2014 lan Raymond B. Pacquing http://www.kritike.org/journal/issue 15/pacquing december2014.pdf ISSN 1908-7330 
continuously torn within. His disobedience leads to a rupture of his existential self. It is a dichotomy that can never be solved. ${ }^{15}$ Fromm says,

... this configuration is precisely one of an existential dichotomy, or to use somewhat less technical language, it is precisely one of a contradiction between man as an animal who is within nature and man as the only thing in nature that has awareness of itself. ${ }^{16}$

However, this existential rupture leaves man not knowing what to do with his new-found freedom. He wants to be secured, to be related, and to belong. He wants to cling to some source to derive his own power. Man wants to be identified and to be recognized. He is forced to renew himself by searching for ways to be reunited again with nature. His animal stature yearns to go back to "the soil of his tribe," yet being aware of himself and his environment through the use of his reason and intelligence, he has to move, to create anew, to transform his life and his environment. In The Art of Loving, Fromm says:

In the beginning of human history, man, though thrown out of the original unity with nature, still clings to this primary bond. He finds his security by going back, or holding on to these primary bonds. He still feels identified with the world of animals, and trees, and tries to find unity by remaining one with the natural world. ${ }^{17}$

He wanted to go back to his original state of animality, fearing that his new-found freedom would bring him nowhere in history. He yearned for the paradisiacal environment. However, according to Fromm, because of his ability to say "no" to God, he was perpetually expelled from paradise. His harmony with nature was broken. Paradise is irreparably lost. Further, saying "no" to God becomes a blessing to man. It is through the act of disobedience

${ }^{15}$ Bischof argues that Fromm feels that man is surrounded by contradictions. Most of life's problems are man-made and, therefore, they can be man-solved. Some of the existential dichotomies are: man lives, yet he dies; man is a part of nature but needs to transcend it; man loves peace yet wages war; man wants to be individualized and be himself yet wants to be socialized and be like everyone else; man behaves rationally but has the strong urge to behave emotionally; man submits himself to higher authorities, yet he also wants to dominate. Cf. Ledford J. Bischof, Interpreting Personality Theories, $2^{\text {nd }}$ ed. (New York: Harper and Row Publishers, 1964), 606.

${ }^{16}$ Fromm, On Being Human, 75.

${ }^{17}$ Erich Fromm, The Art of Loving (London: Thorson Publisher, 1957), 50.

(C) 2014 lan Raymond B. Pacquing

http://www.kritike.org/journal/issue 15/pacquing december2014.pdf

ISSN 1908-7330

(cc) $\mathrm{BY}-\mathrm{NC}$ 
that he becomes human. This act of disobedience allows man to participate in his own humanity.

More than the allegory of Paradise, from a scientific-biologically driven nature, man is basically an animal but the evolution of his brain results in the progress of reason and intelligence. ${ }^{18}$ This gives man the ability to surpass the rest of the animal kingdom. Fromm says:

At the basis of this insoluble existential dichotomy lies an evolutionary, biologically given fact: man emerges from animal evolution ... while at the same time the development of that part of the brain ... has developed far beyond the order of size. This fact makes man ... more helpless than the animal, and gives him the other possibility for a new, even though entirely different kind of strength. ${ }^{19}$

The assertion of Jerome Eikstein contributes to this evolution. He says that the transformation of man from "stoop-four-leggedness into an uprightgaited, two-legged being" widened his power, his sense of self, and his knowledge of his surroundings. ${ }^{20}$ Further, this erect posture of man symbolizes the beginning of human culture. In other words, as two-legged, erected specie, developing the world from his own two hands, the "original $\sin ^{\prime \prime}$ is a consequence of his reactions to the world. ${ }^{21}$ His reactions and counter reactions lead to patterns of fear, anxiety, aggressiveness, and guilt. Man thus satisfies his instincts better than the animals. Unlike the rest of the animal kingdom, it is only man who cooks his food and does not eat it raw. The more

${ }^{18}$ Cf. Maciej Henneberg, “Evolution of the Human Brain: Is Bigger Better?," presented at the Australian Physiological and Pharmacological Society Satellite Symposium on the Evolution of Physiological Processes (June 1998). He argued that the capability of man to use his reason and intelligence gives him the advantage to create tools for the betterment of his environment.

${ }^{19}$ Erich Fromm wrote this paper in 1969, which is the second part of a longer piece entitled, "Freud's Model of Man and Its Social Determinants." However, due to health reasons, one of his students read the second part which is entitled, "My Own Concept of Man," at the Third International Forum in Mexico City. The second part was published in Fromm Forum, 17 (2013), <http://www.fromm-gesellschaft.eu/images/pdf-Dateien/1977g-eng.pdf>. For the evolution of the human brain, see also the articles of John Hawks of the University of Wisconsin in <http://www.scientificamerican.com>. The evolution of the human brain gives us an advantage from the rest of the animal kingdom.

${ }^{20}$ Cf. Jerome Eikstein, "The Rise and Fall of Man," in Journal for the Scientific Study of Religion, 5:1 (1965), 69.

${ }^{21}$ Cf. ibid., 70.

(c) 2014 lan Raymond B. Pacquing

http://www.kritike.org/journal/issue 15/pacquing december2014.pdf

ISSN 1908-7330 


\section{THE CONSCIOUS AND THE UNCONSCIOUS IN MAN}

developed the brain, the less instinctual, and the more rational is the mode of behavior. ${ }^{22}$

The tensions that arise from his animality and "non-animality," from his being thrown into the world without his will (which he shares with other creatures) and his transcending the world, lead him to become a "freak of nature." Just like the rest of the animal kingdom, he is subjected to the physical laws of nature, yet he wants to transcend it. This "duality" within him yearns for the messianism of unity and looks towards the future as the repository of oneness, unity, justice, peace, wisdom, and love. ${ }^{23}$ Man wants to attain an inner equilibrium, which was disturbed by this tension. There is a longing in him to develop further his humanity. Man becomes a wanderer, a searcher for the meaning of his life. Fromm says as a consequence of the disobedience, man perpetually searches for relatedness, belongingness, and unity within himself, with his fellow men, and with the world. Ronald Dropkin shares this insight from Fromm. He says that "some of the needs that may be considered the same for all men are the need for belongingness, achievement and recognition, economic security, to be relatively free from fear, for self-respect and sharing in the values that direct one's life, and for guiding purposes in understanding the world in which one lives." 24 As the bearer of reason and freedom, man has to continuously strive to become himself. He has to develop, to grow, and to mature. Fromm believes that through man's creativity, nature will continuously evolve to become his new haven. It is from man's creative action that humanity's problem may be resolved by improving its potentialities within history. He says:

The real problem is to infer then the core common to all human race from the innumerable manifestations of human nature, the normal as well as the pathological ones, as we can observe them in different individuals and cultures ... Just as the infant is born with all human potentialities which are to develop under favorable social and cultural conditions, so the human race, in the process of history, develops into what it potentially is. ${ }^{25}$

That is why the messianism of Fromm is not intended in passivity but in action aimed toward a better humanity. ${ }^{26}$ The creativity of man entails actions,

\footnotetext{
${ }^{22}$ Cf. Bischof, Interpreting Personality Theories, 606.

${ }^{23}$ Cf. Braune, "Erich Fromm and Thomas Merton," 1.

${ }^{24}$ Ronald H. Dropkin, "Becoming Aware," in Journal of Educational Sociology, 31:6

${ }^{25}$ Erich Fromm, "The Psychology of Normalcy," in Dissent, 1 (Spring 1954), 1.

${ }^{26}$ Cf. Braune, "Erich Fromm and Thomas Merton."
} (1958), 207.

(C) 2014 lan Raymond B. Pacquing

http://www.kritike.org/journal/issue 15/pacquing december2014.pdf

ISSN 1908-7330

$($ (c) $)$ BY-NC 
which should emanate from his own individuality. In improving himself, he must be able to say "be who I am; never be other than myself." 27 For Fromm, the act of disobedience is reclaiming of man's "I am." Although man is related with others, he must be able to maintain his autonomy as individual, as " $I$ am." To be oneself is one of the prerequisites of Fromm in order to move toward this prophetic messianism. My relation towards other men is an experience of humanity i.e., experiencing man "as man in their existential continuum." 28 It is becoming human by nurturing his own peculiarity as human.

Man, as a free individual, is accountable towards himself. He has the responsibility to account for his actions as emanating from himself. His actions, his thinking, and his feelings must be fully human. They must be in consonance to his own peculiar nature. However, this becoming free from paradise entails a burden filled with gigantic responsibility on the part of man. He becomes alone, anxious, and fearful about this new-found freedom. ${ }^{29}$ He is now left alone and isolated in the midst of history without knowing what to do. Nothing is left to him except himself. Fromm says "the awareness of having been torn away from his natural basis and of being an isolated and unrelated fragment in a chaotic world, would lead to insanity (the insane person is one who has lost his place in a structured world, one which he shares with others and in which he can orient himself)." 30 In order to avoid this insanity, he needs to have a sense of himself. He needs to be related and to belong to a world, which he could share with others. He needs to transcend his own existence by struggling to build a better world. The decision does not reside in God any longer but in himself. Since the responsibility rests in him alone, and he himself experiences his own peculiarity, Fromm noted that man fears his new freedom. He has the capacity to escape it or shun it totally. He either regresses by becoming totally isolated or enters into a form of submission. To find security and oneness, he submits himself to authorities and entities outside of himself. He continuously looks for an idol, with whom he can share the burden of his responsibility as man. This submission to authorities/idols is a manifestation of wanting to be reunited back to his place of origin. He wants to regress to infantile situation where he could just follow

${ }^{27}$ Leonard C. Feldstein, "Fromm's Genius was in his Actual Presence," in The Clinical Erich Fromm, ed. by Rainer Funk (Amsterdam and New York: Rodopi Publishers, 2009), 170.

${ }^{28}$ Cf. Ruth Nanda Anshen, "Review of Man for Himself: An Inquiry into the Psychology of Ethics," in The Philosophical Review, 57:5 (Sept., 1948), 521.

${ }^{29}$ Anxiety may be defined through the following: "Anxiety is not an effect of all other affects such as pleasure or sadness. It is rather an ontological aspect of man, rooted in his very existence as such ... . Anxiety is the experience of the threat of imminent non-being ... it is at the center core of his self-esteem and his sense of value as a self, which is one important aspect of his experience of himself as a being." See Eckstein, "The Fall and Rise of Man," 77.

${ }^{30}$ Fromm, "My Own Concept of Man," 2.

(c) 2014 lan Raymond B. Pacquing

http://www.kritike.org/journal/issue 15/pacquing december2014.pdf

ISSN 1908-7330 


\section{THE CONSCIOUS AND THE UNCONSCIOUS IN MAN}

naturally his instincts like what other animals do. What primitive religions did when they worship and imitate animals is a form of infantile regression, says Fromm. ${ }^{31}$ Man's imitation of nature is an expression of his desire to go back to where he originally belongs, where he is nursed by Mother Earth. Man tries to appease nature by creating idols to worship. He formulates laws and regulations on how to submit himself back to nature. Man wants to restore his animality through such worship and imitations. His human energies are transformed in order to make existence bearable. The unbearable obligation moves him to cling to escapism. Man wants to escape this terrible obligation, but he is obliged to create new and better solutions to his dichotomy. As Daniel observes, he (man) "escapes from making choices. He tries to get the other person or the institution in order to take actions for us." 32 Again, Maccoby also noted, "Although we share almost 99 percent of our genetic material with the chimpanzees, the other one percent allows us to choose between either becoming more uniquely and fully human or regressing to tribalism and/or psychopathology .... ."33

The burden of becoming more human rests in man alone. He must develop, grow, and mature, no longer in God's paradise but by creating his own history as a free and rational individual. He must unfold his potentiality within history. For Fromm, man's unfolding in history is actually reconciliation with nature. It is a "progressive affirmation of free will, reason, and love between men." 34 He further says, "it is the history of man's development toward his humanity, towards the development of his specifically human qualities of reason and of love." 35 This is the reason why, for Fromm, the expulsion of man from paradise propelled him into a world of "loneliness, isolation, and homelessness and [he was] left yearning for a union that seemed impossible to reclaim." 36 In the words of Cortina, "man is uprooted from his biological heritage ... humans are both cursed and blessed with the search for a new identity that will give meaning and purpose to their existence." ${ }^{37}$ But since man is armed with reason and freedom, he has to move

${ }^{31}$ Cf. Sigmund Freud, Totem and Taboo, trans. by James Strachey (London: Routledge and Keagan Paul, 1919), 3, 21.

32 Cf. Victor Daniel's unpublished notes on Erich Fromm, $<$ http://www.sonoma.edu/users/Daniel/frommnotes $>$.

33 Michael Maccoby, "The Two Voices of Erich Fromm: The Prophetic and the Analytic," in Society, (July/August 1994). This article is adapted from a lecture given at the Erich Fromm International Symposium, Washington, DC, May 6, 1994.

${ }^{34}$ Ramon Xirau, "Erich Fromm: What Is Man's Struggle?," in B. Landis and E. S. Tauber eds., In the Name of Life. Essays in Honor of Erich Fromm (New York: Holt, Rinehart and Winston, 1971), 150.

${ }^{35}$ Fromm, On Being Human, 19.

${ }^{36}$ Braune, "Erich Fromm and Thomas Merton," 4.

${ }^{37}$ Mauricio Cortina, "Review Essay of Daniel Burston's The Legacy of Erich Fromm," in Jahrbuch der Internationalen Erich-Fromm-Gesellschaft, 4 (1993), 4.

(C) 2014 lan Raymond B. Pacquing

http://www.kritike.org/journal/issue 15/pacquing december2014.pdf

ISSN 1908-7330

$(\mathrm{cc}) \mathrm{EY}_{\mathrm{N}-\mathrm{NC}}$ 
on in history. It is only within history that he can redeem his full human individuality. Fromm believed that this redemption can only happen by squarely facing his human reality. Man has to accept this existential dichotomy and must proceed toward the future. He could not and cannot go back to his original state in paradise. He is barred by "two angels with fiery sword watching the entrance, and man cannot return." 38 Further, he argues that what the serpent says "you shall be as gods" is actually a blessing and not a curse. ${ }^{39}$ When Adam and Eve ate the forbidden fruit, God's authority was threatened in his position as the supreme ruler. God said, "Behold, the man has become like one of us, knowing good and evil." To protect himself, God expelled man from paradise. ${ }^{40}$ It is because of this that man needs to be like him, after all, he was created in the likeness and image of God. ${ }^{41} \mathrm{He}$ possesses this power to transcend his own historical materiality and project himself towards the future. For Fromm, there is no way for man to account his actions but to use his own reason and freedom. He is accountable only to himself as experiencing his self and not to some external authorities outside of himself. The power to move and fully realize himself lies in his own hands. ${ }^{42}$ It is a society in which "man relates to man ... a society which gives him the possibility of transcending nature by creating rather than destroying." 43 Man must be at home with himself and with other fellow men. This prophetic messianism is clearly elaborated in Escape from Freedom. Fromm says:

Man, the more he gains freedom in the sense of emerging from the original oneness with man and nature, and the more he becomes an "individual," has no choice but to unite himself with the world in the spontaneity of love and productive work or else to seek a kind of security by such ties with the world as destroy his freedom and the integrity of his individual self. ${ }^{44}$

Fromm reiterated this unity in his book The Art of Loving. He says:

\footnotetext{
${ }^{38}$ Fromm, On Being Human, 75.

${ }^{39}$ Cf. Braune, 4.

${ }^{40}$ Erich Fromm, You Shall be as Gods (Canada: Holt, Rinehart, and Winston, 1966), 21.

${ }^{41}$ Cf. Ibid.

${ }^{42}$ Cf. Ian Raymond B. Pacquing, "The Power of Man in Fromm's Humanistic Ethics," in Kritike, 7:2 (Dec. 2013), 33-49.

${ }^{43}$ Cf. Daniel, 21.

${ }^{44}$ Merkur Dan quoting the Escape from Freedom, a book written by Fromm in 1941. The analyses of Fromm in this book capture the burden of man's responsibility toward himself in building his own humanity through the peculiar powers that he has. However, Fromm analyzes the different historical events and finds that man wants to escape from freedom by means of submitting himself to authorities that could give him security from his loneliness, anxiety, and homelessness.
}

(c) 2014 lan Raymond B. Pacquing

http://www.kritike.org/journal/issue 15/pacquing december2014.pdf

ISSN 1908-7330 
The deepest need of man is the need to overcome his separateness, to leave the prison of his aloneness. The Absolute failure to achieve this aim means insanity, because the panic of complete isolation can be overcome only by such radical withdrawal from the outside world. ${ }^{45}$

Again, in his book You shall be as gods ${ }^{46}$ he argued further that this messianic unity which he professes brings new harmony within humanity through oneness with nature. Nature becomes the all-loving and nurturing mother. All men are equal for they are children of a mother; they are children of Mother Earth. ${ }^{47}$ Man wants to be who he is and expends his own powers by creating himself and re-creating the lost paradise where he once lived. This happens only when man has a strong sense of himself and has control over his actions, his thoughts, and his feelings. He looks at the capacity for selfawareness, for realism and rationality. Fromm says:

By radical humanism I refer to as the capacity of man to develop his own powers and to arrive at inner harmony and at the establishment of a peaceful world. Radical humanism considers the goal of man to be that of complete independence, and this implies penetrating through fictions and illusions to a full awareness of reality. 48

According to Abraham Kaplan, "the consciousness of who and what we are reveals our true interests and directs us to their fulfillment." 49 Selfawareness realizes itself when man's life becomes his very own. His actions must gear towards his full development. His own thoughts and feelings must emanate from himself. In other words, the claim to be human is one in which man as man becomes the sole proprietor of his own self. As man becomes a part of history, he has to create a new harmony in the historical process. The disrupted union between him and nature entails a struggle to attain his goal toward a better humanity. I quote Anshen:

${ }^{45}$ Fromm, The Art of Loving, 8.

${ }^{46} \mathrm{Cf}$. Fromm, You shall be as Gods, 100.

${ }^{47}$ Fromm, The Art of Loving, 51.

${ }^{48}$ Ramon Xirau, "Erich Fromm: What Is Man's Struggle?," in B. Landis and E. S. Tauber eds., In the Name of Life. Essays in Honor of Erich Fromm (New York: Holt, Rinehart and Winston, 1971), 150-160. $8,1965)$.

${ }^{49}$ Abraham Kaplan, "The Heart of Erich Fromm," in New York Review of Books, (April

(C) 2014 lan Raymond B. Pacquing

http://www.kritike.org/journal/issue 15/pacquing december2014.pdf

ISSN 1908-7330

(cc) BY-NC 
Man has entered a new era of evolutionary history ... . $\mathrm{He}$ is contending with a fundamental change, since he has intervened in the evolutionary process. He must now better appreciate this fact and then develop the wisdom to direct the process toward his fulfillment rather than toward his destruction ... extending his innate capacity and augmenting his ability and his need to communicate as well as his ability to think and to create ... . By intelligent intervention in the evolutionary process man has greatly accelerated and greatly expanded the range of his possibilities. ${ }^{50}$

Fromm echoed this in his book The Sane Society:

Mental Health, in the humanistic sense, is characterized by the ability to love and to create, by the emergence from incestuous ties to the family and nature, and by a sense of identity based on one's experience of the self as the subject and agent of one's own powers, by the grasp of reality inside and outside of ourselves ... the aim of life is to live it intensely, to be fully born, to be fully awake. ${ }^{51}$

A person who experiences his own individual autonomy attains full independence or a genuine sense of the self. ${ }^{52}$ This is the reason why his evolutionary development is a step for him "to become like God, he can imitate God, as it were. Indeed, this idea of the imitation Dei of approximating God requires the premise that man is made in God's image." 53 The process of fulfilling his own individuality by becoming like God is a manifestation that man wants to rise above his own animal stature. He is becoming an autonomous human being, who can truly transcend and understand himself and the world of which he is a part. Couple this with what Fromm calls productive work and love, he believes that the biblical promises of a redemptive paradise would come true. This "paradise" is a manifestation of his hope that "Americans at the end of the $19^{\text {th }}$ century were willing to believe in, and capable in believing in, a society that would fulfill the promises and

\footnotetext{
${ }^{50}$ Ruth Nanda Anshen, "World Perspective," in Erich Fromm, To have or To be (London: Continuum, 1997), ix.

${ }^{51}$ Erich Fromm, The Sane Society (Canada: Holt, Rinehart, and Winston, 1955), 204.

${ }^{52}$ Cf. Bonnie Brennen, "Searching for the Sane Society: Erich Fromm's contribution to Social Theory," in Javnost-The Public, 13:3 (2006), 9.

${ }^{53}$ Fromm, You shall be as Gods, 53.
}

(c) 2014 lan Raymond B. Pacquing

http://www.kritike.org/journal/issue 15/pacquing december2014.pdf

ISSN 1908-7330 
hopes that are at the root of our whole western civilization." 54 Moreover, in his humanist credo, a confession Fromm made in 1960, he says:

I believe in the possible realization of a world in which man can be much, even if he has little ... a world in which "man" is the end, the first and the last; a world in which man can find the way of giving a purpose to his life as well as the strength to live free and without illusions. ${ }^{55}$

History now is his home. History is a continuous remaking of social processes, which are intended for his own individual autonomy. But history has shown that man is like an infant seeking security at the bosom of his mother. ${ }^{56}$ In order to find strength from his powerlessness, and in order for him to find recognition from his isolation, he himself adheres with and clings to the powers of other people and institutions. In his celebrated book Escape from Freedom, Fromm says:

We see that the process of growing human freedom has the same dialectic character that we have noticed in the process of individual growth. On the one hand it is a process of growing strength and integration, mastery of nature, growing power of human reason, and growing solidarity with other human beings. But on the other hand this growing individuation means growing isolation, insecurity, and thereby growing doubt concerning one's role in the universe, the meaning of

${ }^{54}$ Fromm, “Foreword Bellamy," 2.

${ }^{55}$ Fromm, On Being Human, 104.

${ }_{56}$ Cf. Ibid. According to Fromm, "thousands of generations man lived by food gathering and hunting. He was still tied to nature, and afraid of being cast out from her. He identified himself with animals and worshipped these representatives of nature as his gods ... . During this period, he worshipped goddesses as the bearers of natural fertility, experienced himself as the child dependent on the fertility of the earth, on the life-giving breast of Mother. At a time some four thousand years ago, a decisive turn in man's history took place ... . He severed the ties with nature and with Mother, and set himself a new goal, that of being fully born, of being fully awake, of being fully human; of being free ... . Reason and conscience became the principles ... his aim was a society bound by the bonds of brotherly love, justice and truth, a new truly human home to take the place of the irretrievably lost home in nature ... five hundred years before Christ in the great religious system of India, Greece, Palestine, Persia, and China, the idea of unity of mankind assumed a new and more developed expressions. Lao-tse, Buddha, Isajah, Heraclitus, Socrates, and later, on Palestinian soil, Jesus and the Apostles, on American soil, Quetzalcoatl, later again, on Arabian soil, Mohammed, taught the ideas of unity of man, of reason, love, and justice as the goals man must strive for." Fromm, The Sane Society, 354.

(C) 2014 lan Raymond B. Pacquing

http://www.kritike.org/journal/issue 15/pacquing december2014.pdf

ISSN 1908-7330

$($ (c) $)$ BY-NC 
one's life, and with all that a growing feeling of one's own powerlessness and insignificance as an individual. ${ }^{57}$

\section{The Distorted Humanity: Conscious and Unconscious}

The problem of dealing with this humanistic position of Fromm is curbed by forces in history. Man's essential core is dismantled by the unfolding of events most specially the influx of cultural conformism and alienation in the modern world. ${ }^{58}$ In Funk's Foreword to the book On Being Human, Fromm says that humanism spells out the conscious and the unconscious. As a psychoanalyst who followed Freud, Fromm says that the conscious state comprises those parts of man's mental life of which he is fully aware. ${ }^{59}$ It is those experiences, which are observable and are known through the senses. It refers to those experiences that he is aware of in himself and of his social environment. They are those which man knows through his daily encounter with the world and with his fellowmen. It refers to the everyday routine man does to promote a better world. Bischof says, "The state of being conscious enables us to know where we are, what is happening around us, who we are, how we are to go about doing what we are presently doing ...."60 In other words, it is the replica of social representations. They speak of what we know as representations and manifestations of culture and society in the conscious mind. However, Fromm believes that the motivating force behind human behavior is the unconscious instinctual drives and needs. ${ }^{61} \mathrm{In}$ Booerie's explanation, these unconscious strivings are "the source of our motivations, whether they are simple desires for food or sex, neurotic compulsions, or the motives of an artist or scientist. And yet, we are often driven to deny or resist becoming conscious of these motives, and they are often available to us only in disguised form." 62 The unconscious becomes the repository or home of unbridled instincts.

For Freud, this unconscious state is not totally disconnected from the conscious one but rather it (unconscious) serves as an effect of the latter (conscious). Freud says, "If we restore the true connection, we call the original

\footnotetext{
${ }^{57}$ Erich Fromm, The Fear of Freedom (US: Farrar \& Rinehart, 1942), Foreword IX. Outside North America, this book is known as Fear of Freedom. However, in continental Europe, this book is known as Escape from Freedom.

58 Cf. Neil McLaughlin, "How to Become a Forgotten Intellectual: Intellectual Movements and the Rise and Fall of Erich Fromm," in Sociological Forum, 13:2 (Jun., 1998), 222.

${ }^{59} \mathrm{Cf}$. Bischof, Interpreting Personality Theories, 50.

${ }^{60} \mathrm{Cf}$. Ibid.

${ }^{61}$ Cf. Erich Fromm, The Crisis of Psychoanalysis (New York: Henry Holt and Company, 1970), 138.

62 George Boeree, Theories of Personality, 4/19, <http://www.ship.edu/ \%7Ecgboeree/perscontents.html>.
}

(c) 2014 lan Raymond B. Pacquing http://www.kritike.org/journal/issue 15/pacquing december2014.pdf ISSN 1908-7330 


\section{THE CONSCIOUS AND THE UNCONSCIOUS IN MAN}

effect 'unconscious,' although the effect was never unconscious but its ideational presentation had undergone repression." 63 Here, Freud seeks to explain that the unconscious is restrained from being expressed. The wish or desire, which is supposed to be expressed, is repressed. According to Freud, the memories of the past, particularly those childhood experiences which brought anxieties and pain, are blocked from the conscious mind. It was unconsciously blocked and prevented from acting. The prevention, exclusion, or blocking from the conscious mind are done without the knowledge of the agent. ${ }^{64}$ For Freud, the unconscious are representations of something hidden, which motivates man to behave and act in certain ways. Vanderplas explains, "Conscious acts alone do not enable us to account for certain aspects of slips of tongue and of other parapraxes, of dreams, of mental symptoms or obsessions in the sick, let alone the sudden inspirations of healthy persons." 65 Since the wish or desire is repressed, it forces the individual to sublimate his desire to some other forms. That is why, for Freud, the theory of repression becomes the pillar upon which psychoanalysis rests. ${ }^{66}$

Fromm follows this Freudian principle, but he moves further from Freud. While Freud is concerned with those instinctual individual drives, which are repressed, what he did not see was the cause of the repression. As already proven by analytic authors, repression is caused by the pressure from social structures like religion, customs, policies, and education. ${ }^{67}$ These social structures, says Fromm, allow only what is demanded from man. There are instinctual drives, which are only permitted by the very social structures which he comes from. These instinctual drives are filtered by society and would only appear as society would have wanted them to. Social filters, according to Fromm, serve as a dynamic mechanism to preserve the structural foundations of society. Thus, even if one wants to engage in extramarital affairs, if society does not allow it, that desire is repressed. ${ }^{68}$ These instinctual drives in man are not socially legalized and accepted. Through repression, a certain character is built in order to be in consonance with the social structures. In the Foreword to Fromm's Revision of Psychoanalysis, Rainer Funk says man is controlled by social factors, which he believes to be so natural in the social arena, but unknown to him, these are

\footnotetext{
${ }^{63}$ Abraham Edel, "The Concept of the Unconscious: Some analytic Preliminaries," in Philosophy of Science, 31:1 (Jan., 1964), 19. Italics mine.

${ }^{64}$ Cf. Bischof, Interpreting Personality Theories, 53.

65 J.M. Vanderplas, "Psychoanalytic Theory," in Controversial Issues in Psychology (Boston: Houghton Mifflin, 1966), 412.

${ }^{66}$ Cf. Stanley Hayman, "Psychoanalysis and the Climate of Tragedy," in B. Nelson ed., Freud and the 20th Century (London: G. Allen und Unwin, 1958), 171.

${ }^{67}$ Cf. Fromm, The Crisis of Psychoanalysis, 141.

${ }^{68} \mathrm{Cf}$. Erich Fromm, The Greatness and Limitations of Freud's Thought (New York: Harper and Row, 1979), 13.

(C) 2014 lan Raymond B. Pacquing

http://www.kritike.org/journal/issue 15/pacquing december2014.pdf

ISSN 1908-7330

(cc) $\mathrm{BY}-\mathrm{NC}$
} 
the results of reified ideologies. Man rationalizes the foundations of social structures. Fromm says, "Common sense, the constraints of circumstances and of so-called normalcy, and the self-evident are rationalized expressions of the fixation on idols and the belief in illusions and ideologies." ${ }^{69}$ What we believe to be the smooth flow of social transactions are rationalizations emanating from ideologies perpetuated by those who are in authority. They serve as a cover up of what ought to be desired of man and for man. Psychoanalysis then is to excavate these repressed drives in order to know which desires and drives are apt for the development of man. It is to know those repressed instinctual desires, which originally wanted to be expressed. Eisktein says that the psychoanalytical methods attempt to excavate the underlying causes through understanding the original "abode" of man's dreams i.e., understanding the myth that enveloped his social existence. ${ }^{70}$ Fromm believes that this unconscious region is the commonality that men share so that they can understand each other but are obstructed by ideologies and illusions. The unconscious speaks of the universal essence of man, which becomes the "essential human core about which universally valid empirical knowledge can be attained."71 Each human expression is a representation of this universal man. Each man becomes a symbol of this essential core. The confirmation of this universal nature of man is found in our dreams wherein our unconscious speaks to us. ${ }^{72}$ Samuel Baron says, "Fromm maintains that what the dream says is a highly personal expression of the dreamer's own thinking and feelings." 73 Psychoanalysis says that dreams are the royal road to what is unconscious. ${ }^{74}$ Even Freud himself accepted that dreams are the via regia towards the interpretation of the unconscious. ${ }^{75}$ We are cut from our day-to-day experiences of the world around us. In The Forgotten Language, Fromm argues that in our dreams, man regresses into an animal-like state of mind, which for Jung, is the unconscious state which is more superior and

\footnotetext{
${ }^{69}$ Rainer Funk, Foreword to Revision of Psychoanalysis (New York: Open Road, Integrated Media, 2013).

${ }^{70}$ Cf. Eikstein, "The Rise and Fall of Man," 70.

${ }^{71}$ Cf. Rainer Funk, "The Humanistic Foundations of Psychoanalysis According to Fromm," presented at the $34^{\text {th }}$ Winter-Meeting of the American Academy of Psychoanalysis, December 9, 1990, San Antonio, Texas.

72 Cf. Erich Fromm, The Forgotten Language. An Introduction to the Understanding of Dreams, Fairy Tales and Myths (New York: Rinehart and Co., 1951), 9.

73 Samuel Baron, "Review of The Forgotten Language. An Introduction to the Understanding of Dreams, Fairy Tales and Myths," in Psychoanalysis. Journal of the National Association for Psychoanalysis, 1 (1952), 78f.

${ }^{74}$ Cf. Jorge Silva Garcia, "Notes on Erich Fromm and the Understanding of Dreams," in Erich Fromm Archive, (1982), 2.

75 Sigmund Freud, "Origin and Development of Psychoanalysis," in American Journal of Psychology, 21 (1910), 200.
}

(c) 2014 lan Raymond B. Pacquing

http://www.kritike.org/journal/issue 15/pacquing december2014.pdf

ISSN 1908-7330 


\section{THE CONSCIOUS AND THE UNCONSCIOUS IN MAN}

purposive than the actual state. ${ }^{76}$ Our dreams, Fromm says, "allows both our worst and our best sides to come out; thus, during our dreams we can be less intelligent, less wise, and less decent than our waking lives; on the other hand, we can also be better and wiser than we are then." 77 That is why the unconscious "always represents the whole man in the whole gamut of his potentialities, both darkness and for light."78 Kleiner and Linton say that through our dreams, the unconscious becomes "a language in which inner experience, feelings, and thoughts are expressed as if they were sensory experiences in the outer world."79 Dreams become the universal language, which assumes the role of a secret code to untangle the mysteries of the unconscious. ${ }^{80}$ Through our dreams, the higher order of reason might be at the center of who we are rather than what we are in actual life. Millet says that who we want to be, "the real me," becomes more evident in our dreams than in our waking state..$^{81}$ The unconscious then goes down deep to the very isolation and loneliness of being human. It speaks of the unspoken truth in him. Being fully human can only be known by unraveling the mysteries within the unconscious. It is within that region that the entire spectrums of human endeavors reside. Fromm says:

What is contained in the unconscious, then, is not just good or evil, the rational or irrational; both are contained there; there we find all that is human. The unconscious is the whole man-minus, that part of man which corresponds to his society. The consciousness represents social man i.e., man subject to the accidental limitations imposed by the historical situation into which an individual is thrown. Unconscious represents the universal man, the whole man rooted in the cosmos. ${ }^{82}$

Quoting Fromm, Funk says, "... man, in any culture, is faced by the gamut of possibilities: He is the archaic man, the beast of prey, the cannibal, the idolater; but he is also the being with the capacity for reason and love, for

\footnotetext{
${ }^{76}$ Cf. Baron, "Review of The Forgotten Language. An Introduction to the Understanding of Dreams, Fairy Tales and Myths," 78-79.

${ }_{77}$ Fromm, The Forgotten Language, 36.

${ }^{78}$ Funk, "The Humanistic Foundations of Psychoanalysis," 3.

${ }^{79}$ Robin David Linton and Brian H. Kleiner, "Using Dreams To Enhance Selfawareness," in Journal of Religion and Psychical Research, 12:1 (January, 1989), 15.

${ }^{80}$ Cf. Baron, Review of The Forgotten Language. An Introduction to the Understanding of Dreams, Fairy Tales and Myths," 78.

${ }^{81}$ John A.P. Millet, "Review of The Forgotten Language," in Pastoral Theology, 3 (April, 1952), 47.

${ }^{82}$ Funk quoting Fromm, "The Humanistic Foundation of Psychoanalysis," 3.

(C) 2014 lan Raymond B. Pacquing

http://www.kritike.org/journal/issue 15/pacquing december2014.pdf

ISSN 1908-7330

(cc) $\mathrm{BY}-\mathrm{NC}$
} 
justice." 83 One may perceive somebody with these particular behavioral traits expressed through human actions, and as far as the consciousness is concerned, these are all what we can know. However, in one's unconscious reside all the possibilities that one may potentially become. That is why, for Fromm, this gamut of possibilities enunciates what being human is all about. The unconscious is the repository of the humanity found in each human being, and each human expression, each human action or trait is just one among those possibilities. The essence of man is his humanity. We cannot find or observe this very essence in our daily existence. What we observe and know through our senses is what our conscious mind tells us. It is what society wants us to portray. What we don't know is the very humanity in us that yearns to be expressed and understood. The existential dichotomy then in man is a kind of tension, which wants to absolutize and to unify himself as himself, seeking his own individual autonomy through the uncovering of those possibilities that lie beneath the unconscious. Through the unconscious, man comes to realize himself as a project wanting to be fulfilled. We can find in the unconscious what potentialities could be developed further in man. ${ }^{84}$ Mondin was impelled to say that man is an impossible possibility for becoming human is "so vast, so varied, and so multiform, that every definition demonstrates itself as too limited." 85 We can also say with him that every conscious knowledge of man is too limited that what we tend to forget is his very unconscious, which is the haven of becoming human. In the Heart of Man, Fromm says, "the humanistic experience consists in the feeling that nothing human is alien to one, that 'I am you,' that one can understand another human being because both of us share as our common possession that same element of human existence." 86 To allow then the unconscious to become conscious, man begins to grow and unfurls his potentials. He becomes who he is as man. To point out his humanism, Fromm asks, "if men differed in their basic psychic and mental structure, how could we speak of humanity in more than a physiological and anatomical sense? How could we understand the art of entirely different cultures, their myths, their drama, their sculpture, were it not a fact that we all share the same human nature?" 87 Further, Fromm admired Spinoza, Herder, and Goethe for "they believed that every individual carries within himself not only his individuality but also all of humanity with all its potentialities." 88 The entire spectrum then of Fromm's

\footnotetext{
${ }^{83}$ Editor's Foreword, On Being Human, 10.

${ }^{84} \mathrm{Cf}$. Edel, "The Concept of the Unconscious," 20.

85 Battista Mondin, Philosophical Anthropology (Rome: Urbaniana University Press,

${ }^{86}$ Fromm, On Being Human, 11.

${ }^{87}$ Erich Fromm, Beyond the Chain of Illusion (London: Simon and Schuster, 1962), 20.

88 Ibid., 21.
} 1985), 19.

(C) 2014 lan Raymond B. Pacquing

http://www.kritike.org/journal/issue 15/pacquing december2014.pdf

ISSN 1908-7330 


\section{THE CONSCIOUS AND THE UNCONSCIOUS IN MAN}

thinking as influenced by Hasidic culture is centered on man - the thinking man, the acting man, the feeling man - the multifarious faces of him, in all his unity and diversity, as the creator and maker of his own life, his possibilities and impossibilities, his conscious and unconscious - all of these speak of his very capacity to move forward in the evolutionary process in history. This capacity gears toward self-awareness, rationality, and realism. Man does realize himself not only through vertical transcendence but through historical transcendence in that evolutionary process through reason and love. ${ }^{89}$ Reiterating his concept of humanism to a group of political scientists and economists, Fromm says that the "right of each man to unfold as an individual and as a human being ... the right to be oneself" $f^{\prime 90}$ becomes a fundamental issue in his philosophical anthropology. Further, he asserts that, "If a person fails to attain freedom, spontaneity, a genuine expression of self, he may be considered to have a severe defect, provided we assume that freedom and spontaneity are the objective goals to be attained by every human being." 91 The fact that $21^{\text {st }}$ century man strives to get rid of all the limitations and boundaries set upon him by society implies that he wants to be determined as man. He wants to be unbounded by any social constructs that would delimit his capacity to become human. Twenty-first century man wants to be self-determined by confining himself to his own individual autonomy by wanting to construct society in a new way, ${ }^{92}$ in order for him to conceptualize his goal for self-realization.

$$
\begin{array}{r}
\text { Department of Philosophy } \\
\text { The Graduate School } \\
\text { University of Santo Tomas, Philippines }
\end{array}
$$

\section{References}

Anshen, Ruth Nanda, "Review of Man for Himself: An Inquiry into the Psychology of Ethics," in The Philosophical Review, 57:5 (Sept., 1948).

"World Perspective," in Erich Fromm, To have or To be (London: Continuum, 1997).

Baron, Samuel, "Review of The Forgotten Language. An Introduction to the Understanding of Dreams, Fairy Tales and Myths," in Psychoanalysis. Journal of the National Association for Psychoanalysis, 1 (1952).

\footnotetext{
${ }^{89}$ Cf. Kaplan, "The Heart of Erich Fromm," 2.

${ }^{90}$ Cf. Erich Fromm, "The Automaton Citizen and Human Rights," in Fromm Forum, 12 (2008), 11-16.

${ }^{91}$ Fromm, "The Psychology of Normalcy," 2.

${ }_{92}$ Cf. Rainer Funk, "Striving for Unboundedness and Its Impact on Psychoanalytic Treatment," in Fromm Forum, 17 (2013), 22-28.

(C) 2014 lan Raymond B. Pacquing

http://www.kritike.org/journal/issue 15/pacquing december2014.pdf

ISSN 1908-7330

(cc) BY-NC
} 
Bischof, Ledford J., Interpreting Personality Theories, $2^{\text {nd }}$ ed. (New York: Harper and Row Publishers, 1964).

Boeree, George, Theories of Personality, 4/19, <http://www.ship.edu/ \%7Ecgboeree/perscontents.html>.

Braune Joanne, "Erich Fromm and Thomas Merton: Biophilia, Necrophilia, and Messianism" in Fromm Forum, 15 (2011), <http://www.frommgesellschaft.eu/images/pdf-Dateien/Braune_J_2011.pdf $>$.

Brennen, Bonnie, "Searching for the Sane Society: Erich Fromm's contribution to Social Theory," in Javnost-The Public, 13:3 (2006).

Cortina, Mauricio, "Review Essay of Daniel Burston's The Legacy of Erich Fromm," in Jahrbuch der Internationalen Erich-Fromm-Gesellschaft, 4 (1993).

Dan, Merkur, "Erich Fromm's Humanistic Psychoanalysis," in Explorations of Psychoanalytic Mystics, 11 (2010).

Daniel, Victor, Unpublished Notes on Erich Fromm, $<$ http://www.sonoma.edu/users/Daniel/frommnotes $>$.

Dropkin, Ronald H., "Becoming Aware," in Journal of Educational Sociology, 31:6 (1958).

Edel, Abraham, "The Concept of the Unconscious: Some analytic Preliminaries," in Philosophy of Science, 31:1 (Jan., 1964).

Eikstein, Jerome, "The Rise and Fall of Man," in Journal for the Scientific Study of Religion, 5:1 (1965).

Feldstein, Leonard C., "Fromm's Genius was in his Actual Presence," in The Clinical Erich Fromm, ed. by Rainer Funk (Amsterdam and New York: Rodopi Publishers, 2009).

Freud, Sigmund, "Origin and Development of Psychoanalysis," in American Journal of Psychology, 21 (1910).

Totem and Taboo, trans. by James Strachey (London: Routledge and Keagan Paul, 1919).

Fromm, Erich, "Foreword Bellamy," in The Literary Estate of Fromm (New York, 1960).

, "My Own Concept of Man," in Fromm Forum, 17 (2013), $<$ http://www.fromm-gesellschaft.eu/images/pdf-Dateien/1977geng.pdf $>$.

"The Automaton Citizen and Human Rights," in Fromm Forum, 12 (2008).

"The Psychology of Normalcy," in Dissent, 1 (Spring 1954).

Beyond the Chain of Illusion (London: Simon and Schuster, 1962).

Fear of Freedom (US: Farrar \& Rinehart, 1942).

For the Love of Life, trans. by Robert and Rita Kimber (New York:

The Free Press, 1986).

(C) 2014 lan Raymond B. Pacquing

http://www.kritike.org/journal/issue 15/pacquing december2014.pdf

ISSN 1908-7330 


\section{THE CONSCIOUS AND THE UNCONSCIOUS IN MAN}

Man for Himself: An Inquiry into the Psychology of Ethics (New York: Henry Holt and Company, 1990). , On Being Human, ed. by Rainer Funk (New York: Continuum, 1999).

Revolution of Hope (New York: American Mental Health Foundation, Inc., 1970).

Sane Society (New York: Holt, Rinehart, and Winston, 1955).

The Art of Loving (London: Thorson Publisher, 1957).

, The Fear of Freedom (US: Farrar \& Rinehart, 1942).

The Forgotten Language. An Introduction to the Understanding of

Dreams, Fairy Tales and Myths (New York: Rinehart and Co., 1951).

The Greatness and Limitations of Freud's Thought (New York:

Harper and Row, 1979).

The Sane Society (Canada: Holt, Rinehart, and Winston, 1955).

You Shall be as Gods (Canada: Holt, Rinehart, and Winston,

1966), 21.

The Crisis of Psychoanalysis (New York: Henry Holt and Company, 1970).

Funk, Rainer, "Striving for Unboundedness and Its Impact on Psychoanalytic Treatment," in Fromm Forum, 17 (2013).

"The Humanistic Foundation of Psychoanalysis According to

Erich Fromm," presented at the $34^{\text {th }}$ Winter-Meeting of the American Academy of Psychoanalysis (December 9, 1990).

, "The Humanistic Foundations of Psychoanalysis According to

Fromm," presented at the $34^{\text {th }}$ Winter-Meeting of the American

Academy of Psychoanalysis, December 9, 1990, San Antonio, Texas. 1982).

Erich Fromm: The Courage to be Human (New York: Continuum,

Foreword to Revision of Psychoanalysis (New York: Open Road, Integrated Media, 2013).

Garcia, Jorge Silva, "Notes on Erich Fromm and the Understanding of Dreams," in Erich Fromm Archive, (1982).

Hayman, Stanley, "Psychoanalysis and the Climate of Tragedy," in B. Nelson ed., Freud and the 20th Century (London: G. Allen und Unwin, 1958).

Henneberg, Maciej, "Evolution of the Human Brain: Is Bigger Better?," presented at the Australian Physiological and Pharmacological Society Satellite Symposium on the Evolution of Physiological Processes (June 1998).

Kaplan, Abraham, "The Heart of Erich Fromm," in New York Review of Books, (April 8, 1965).

(C) 2014 lan Raymond B. Pacquing

http://www.kritike.org/journal/issue 15/pacquing december2014.pdf

ISSN 1908-7330 
Linton, Robin David and Brian H. Kleiner, "Using Dreams To Enhance Selfawareness," in Journal of Religion and Psychical Research, 12:1 (January, 1989).

Maccoby, Michael, "The Two Voices of Erich Fromm: The Prophetic and the Analytic," in Society, (July/August 1994).

McLaughlin, Neil, "How to Become a Forgotten Intellectual: Intellectual Movements and the Rise and Fall of Erich Fromm," in Sociological Forum, 13:2 (Jun., 1998).

Millet, John A.P., "Review of The Forgotten Language," in Pastoral Theology, 3 (April, 1952).

Mondin, Battista, Philosophical Anthropology (Rome: Urbaniana University Press, 1985).

Pacquing, Ian Raymond B., "The Power of Man in Fromm's Humanistic Ethics," in Kritike, 7:2 (Dec. 2013).

Vanderplas, J.M., "Psychoanalytic Theory," in Controversial Issues in Psychology (Boston: Houghton Mifflin, 1966).

Wilde Lawrence, "In Search of Solidarity: Ethics of Politics of Erich Fromm," in Contemporary Politics, 6:1 (2000).

Xirau, Ramon, “Erich Fromm: What Is Man's Struggle?," in B. Landis and E. S. Tauber eds., In the Name of Life. Essays in Honor of Erich Fromm (New York: Holt, Rinehart and Winston, 1971).

(C) 2014 lan Raymond B. Pacquing http://www.kritike.org/journal/issue 15/pacquing december2014.pdf 